Feature Article

\title{
An overview of heavy metal contamination in coastal sediments of Sri Lanka
}

\author{
A.M.N.M. Adikaram ${ }^{1 *}$ and H.M.T.G.A. Pitawala ${ }^{2}$ \\ ${ }^{I}$ Department of Physical Sciences, Faculty of Applied Sciences, South Eastern University, \\ Sri Lanka \\ ${ }^{2}$ Department of Geology, Faculty of Science, University of Peradeniya, Sri Lanka
}

\begin{abstract}
Coastal sediments are often subjected to heavy metal contamination as they reside at the marginal environments of anthropological water releases. These sediments provide the habitat for marine aquatic life of seafood. Therefore, heavy metal contamination in coastal sediments is one of the major environmental concerns. The coastal belt of Sri Lanka is highly urbanized with high population (59\% of Sri Lankan population) and is mostly depend on the sea. Therefore, anthropogenic inputs of pollutants in to the marine environments have been increased during last decades. Heavy metal contamination of the coastal sediments of Sri Lanka has been discussed by several studies, focusing on selected coastal regions. In this article, previous studies have been reviewed in order to understand the contamination status and ecological risks due to heavy metal accumulations.Despite the sampling location, the elemental distribution of coastal lagoonalsediments shows similar trend indicating the dominance of natural elemental sources rather the anthropogenic influences. The concentrations of As and $\mathrm{Cr}$ in sediments are high compared to the upper continental crust values which is a characteristic feature in possible source rocks, soils and sediments of Sri Lanka. Theresults of the previous studies indicate thatcoastal sediments are low to moderately contaminated but notat ecological risk. However, anthropogenic activities are highly variable across the coastal regions. Since limited results of the previous studies is not enough to get an overview of the heavy metal concentrationsaround the island, urgent need for a spatial and temporal geochemical database for coastal sediments of Sri Lanka is emphasized.
\end{abstract}

Keywords: contamination, coastal, metals and sediments

\section{Introduction}

Environmental contaminants are in three categories:(a) stable trace elements (b) organic substances and (c) radionuclides (Tornero andd'Alcalà, 2014). United States Environmental Protection Agency (USEPA) has chosen the following trace elements including heavy metalssuch as $\mathrm{Ag}, \mathrm{As}, \mathrm{Ba}, \mathrm{Be}$, $\mathrm{Cd}, \mathrm{Co}, \mathrm{Cr}, \mathrm{Cu}, \mathrm{Hg}, \mathrm{Mn}, \mathrm{Mo}, \mathrm{Ni}, \mathrm{Pb}, \mathrm{Sb}, \mathrm{Se}$ and $\mathrm{Zn}$ that is toxic in desired excessive concentrations. The list has expanded later by several authors (McBridge, 1995; Chen and Ma, 1998).

*Correspondence: maduryaa@gmail.com

Tel: +94718318140

ISSN 2235-9370 Print/ISSN 2235-9362 Online @ C University of Sri Jayewardenepura 
When a substance is above the level of background it is said to be as "contaminated". When it is adversely affected on biological communities, it is said to be as"polluted" (Chapman, 2007). Heavy metal contamination in natural environments is a severe environmental problem due to their natural toxicity, persistence, vast sources and non-degradability (Wang et al., 2013). Heavy metals get into natural environments from effluents of industries, agriculture and aquaculture practices, and municipal and domestic wastes (Tornero andd'Alcalà, 2014). Marineand coastal environments have been paid more attention because they are the ultimate settings of heavy metal accumulationsand human concern for seafood (Wang et al., 2005).Bioaccumulation, bio-magnification by food chains, destruction to organisms and ecological systems and consequently damage to ecological goods and services are the adverse effects of heavy metal contaminations (Newton et al., 2013; Tornero andd'Alcalà, 2014). Therefore, it is essential to monitor the present contamination status in marine and coastal environments.

Sri Lankan coastline is about $1,920 \mathrm{~km}$ long and encompasses about $50 \%$ of the Bay of Bengal (Katupotha, 1989).Different coastal features such as lagoons, estuaries, sediment bars and spits, dunes, wave cuts, arches and cliffs which are characterized by erosional and depositional processes are presentaround the island (Katupotha, 2007). The origin and evolution of coastal landforms of the country was activated during the Quaternary period and the sea level reaches its present status about 3000 year BP (Ranasinghe et al., 2013). Several studies on different coastal landforms of Sri Lanka have been reviewed in this article to summarize the current status of coastal sediment contamination. This article reviews the existing literature on the concentrations of selected trace elements in the coastal regions of Sri Lanka and risk of contamination of the coastal ecosystems by them.

\section{Coastal environment of Sri Lanka}

The climate of Sri Lanka is tropical with diversified rainfalls from both southwest (SW) and northeast (NE) monsoons. In general, high rainfall is recorded during May to September due to SW monsoons and low rainfall during November to February due to NE monsoons. Altogether 103 main rivers are flowing to the coastal low lands from the central part of the country. The river discharges are timely changed with monsoonal rainfall effect. Huge sediment loads are carried through the river channels, and hence river channels are the basic sediment supplier for the coastal zones. Large scale storm or cyclone has not been recorded during past decades except the tsunami occurred in 2004. The temperature ranges from $16^{\circ} \mathrm{C}$ to $32^{\circ} \mathrm{C}$ across the country. The lowest temperature recorded in the central highlands and highest temperatures are recorded in constantly southeastern and eastern coastal areas. The tidal effect of the island is micro-scale and hence no considerable effect on sedimentation in coastal zones except the regionally developing sea currents.

Many of the coastal zones of Sri Lanka are densely populated due to clear and shallow beaches, corals and hot sun. About $59 \%$ of the total population of Sri Lanka is associated to the coastal regions (Nayanananda, 2007). Most of the industrialized capital cities are located around the coastal margins of the country. Sea around the country receives nutrient rich currents, therefore other than point sources of contaminants non-point source such as storm water and dust can contribute for contamination. Fishing industry is famous in Sri Lanka and fish processing units are established around the coastal areas. Western and southern coastal regions arehighly industrialized and densely populated. Thus,effluents that comes from industries such as petroleum refining, ship repairing, tires and thermal industries other than the huge municipal and domestic leachates are mixed with natural waters are ended up at the sea.Additionally, minor water based industries such as foundry, laundry, tannery, paper industries, service stations and "batik"fabric die work are commonly observed in coastal low lands of Sri Lanka where tourists are attracted. 


\section{Levels of contaminants}

In presentarticle, heavy metals and As concentrations in sediments ofseven main semi-enclosed marginal marine water bodiesand capital city of Sri Lanka are summarized from published data. These recent publications are done by collecting surface sediment fractions of each semi-enclosed body. Sampling locations areTrincomalee bay, Batticaloa lagoon, Hambanthota lagoon, Galle harbor, Hikkaduwa lagoon, Beruwala harbor, Muthurajawela peat deposit and surface sediments of Colombo city (Dissanayake, 1987; Jayawardana et al., 2012; Young et al., 2014; Silva, 2015; Heath et al., 2016; Adikaram et al., 2017).Geographical distribution of the concentrations of the selected heavy metals of Sri Lanka is shown in Figure 1 (Dissanayake, 1987; Jayawardana et al., 2012; Young et al., 2014; Silva, 2015; Heath et al., 2016; Adikaram et al., 2017).Concentrations of $\mathrm{Zn}$ and $\mathrm{Cr}$ are significant in all natural lagoonal systems including Muthurajawela peat deposit with compared to the other elements. The two harbors show high $\mathrm{Pb}$ concentrations. Substantial enrichments of $\mathrm{Zn}$ and $\mathrm{Cu}$ are observed in the city sediments of the Colombo region.

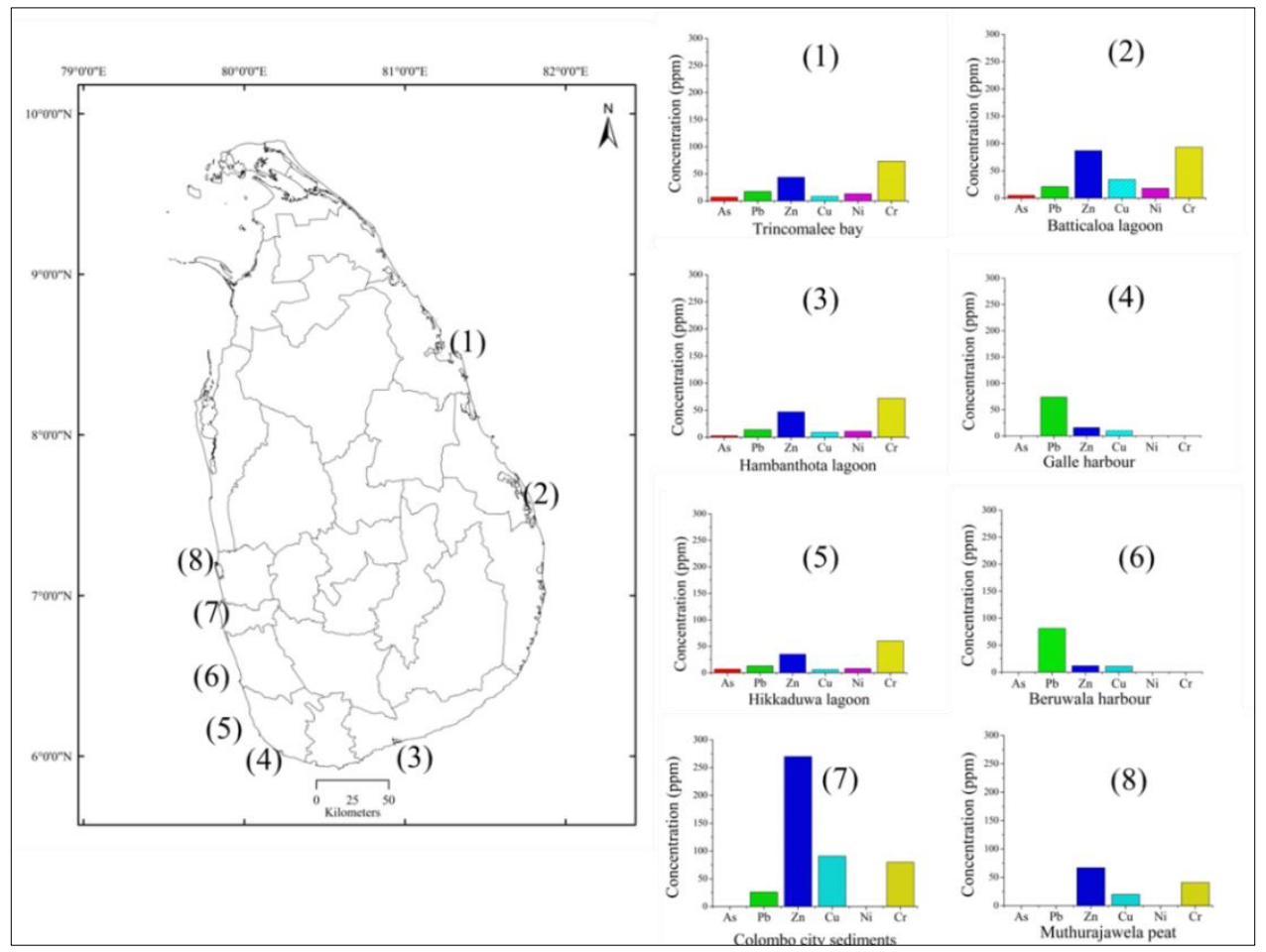

Figure 1: Geographical distribution of heavy metal concentrations in coastal sediments of Sri Lanka.(After Dissanayake, 1987; Jayawardana et al., 2012; Young et al., 2014; Silva, 2015; Herath et al., 2016; Adikaram et al., 2017).

Average concentrations of $\mathrm{As}, \mathrm{Pb}, \mathrm{Zn}, \mathrm{Cu}, \mathrm{Ni}$ and $\mathrm{Cr}$ of the semi-enclosed water bodies of Sri Lanka, other published data in different regions of the world and international standards are summarized in Table1. It is noted that the sediments of Sri Lankan coastal zones are not contaminated with compared to other compared marine environments of the world. 
Table 1: Concentrations of heavy metals and As in coastal sediments of Sri Lanka and comparison with other coasts.

\begin{tabular}{|c|c|c|c|c|c|c|c|c|}
\hline \multirow[t]{2}{*}{ Country } & \multirow[t]{2}{*}{ Location } & \multicolumn{6}{|c|}{ Concentration (ppm) } & \\
\hline & & As & $\mathrm{Pb}$ & $\mathrm{Zn}$ & $\mathrm{Cu}$ & $\mathrm{Ni}$ & $\mathrm{Cr}$ & \\
\hline \multirow[t]{10}{*}{ Sri Lanka } & Batticaloa lagoon & $5(3-10)^{*}$ & $21(14-26)$ & $87(21-155)$ & $34(6-216)$ & $18(7-41)$ & $93(52-146)$ & Adikaram et al., 2017 \\
\hline & Trincomalee, inner harbour & $7(3-19)$ & $23(3-103)$ & $49(21-152)$ & $13(2-41)$ & $16(3-57)$ & $73(26-192)$ & Young et al., 2014 \\
\hline & $\begin{array}{l}\text { Trincomalee, Thambalagam } \\
\text { bay }\end{array}$ & $10(2-43)$ & $14(8-20)$ & $31(9-79)$ & $6(0-23)$ & $11(4-46)$ & $50(11-181)$ & Young et al., 2014 \\
\hline & Trincomalee, Koddiyar bay & $4(2-9)$ & $15(9-20)$ & $51(6-181)$ & $6(2-14)$ & $13(0-27)$ & $96(7-356)$ & Young et al., 2014 \\
\hline & Hikkaduwa lagoon & $7(3-11)$ & $13(8-17)$ & $35(8-55)$ & $6(2-9)$ & $8(0-20)$ & $60(45-84)$ & Jayawardana et al., 2012 \\
\hline & Hambanthota lagoon & $3(3-4)$ & $14(14-15)$ & $47(38-72)$ & $9(5-12)$ & $11(10-17)$ & $72(61-78)$ & Jayawardana et al., 2012 \\
\hline & Galle fishery harbour & nd & $74(61-87)$ & $16(1-68)$ & $10(7-16)$ & nd & nd & Silva $(2015)$ \\
\hline & Beruwala fishery harbour & nd & $80(37-102)$ & $12(0-50)$ & $11(5-15)$ & nd & nd & Silva (2015) \\
\hline & Muthurajawela peat & nd & nd & $67(26-262)$ & $20(12-37)$ & nd & $41(20-84)$ & Dissanayake (1987) \\
\hline & Colombo city dust & nd & $26(0-76)$ & $\begin{array}{c}270(53- \\
625)\end{array}$ & $\begin{array}{c}91(28- \\
319)\end{array}$ & nd & $80(47-152)$ & Herath et al., (2016) \\
\hline \multirow[t]{6}{*}{ India } & Gulf of Mannar & nd & 16 & 73 & 57 & 24 & 177 & Jonathan et al.,2009 \\
\hline & Kalpakkam & nd & 22 & 119 & nd & 53 & 118 & Selvaraj et al., 2004 \\
\hline & Pondicherry & nd & 33 & 52 & 48 & 20 & 334 & Solali et al, 2013 \\
\hline & Gange's estuary & nd & 29 & 71 & 26 & 32 & 67 & Subramanian et al., 1988 \\
\hline & Krishna Estuary & nd & 4 & 1482 & 59 & 149 & 174 & $\begin{array}{l}\text { Ramesh and } \\
\text { Subramanium, } 1988\end{array}$ \\
\hline & West Bengal & nd & 17 & 74 & 36 & 34 & 37 & Sarkar et al., 2004 \\
\hline Bangladesh & Chittagong coast, & nd & 18 & 355 & 189 & 33 & 658 & Hasan et al., 2013 \\
\hline Tunisia & Mediterrnian sea & $(13-36)$ & $(65-152)$ & $(47-546)$ & $(8-29)$ & $(9-31)$ & nd & Zohra and Habib, 2016 \\
\hline China & Bhohai bay & nd & $(21-66)$ & $(55-457)$ & $(20-63)$ & $(23-53)$ & $(60-224)$ & Gao and Chen, 2012 \\
\hline \multirow[t]{2}{*}{ SQG } & TEC & 10 & 36 & 121 & 32 & 23 & 43 & McDonald et al., 1996 \\
\hline & PEC & 33 & 128 & 459 & 149 & 49 & 111 & McDonald et al., 1997 \\
\hline
\end{tabular}


The concentration of As and $\mathrm{Cr}$ in coastal sediments of Sri Lanka is high with compared to the upper continental crust (UCC) values (Figure. 1; Taylor and McLennan, 1985). The possible source country rock types are characterized in high concentrations of $\mathrm{As}$ and $\mathrm{Cr}$ and this might be the reason for the enrichments of such elements (Young et al., 2014).

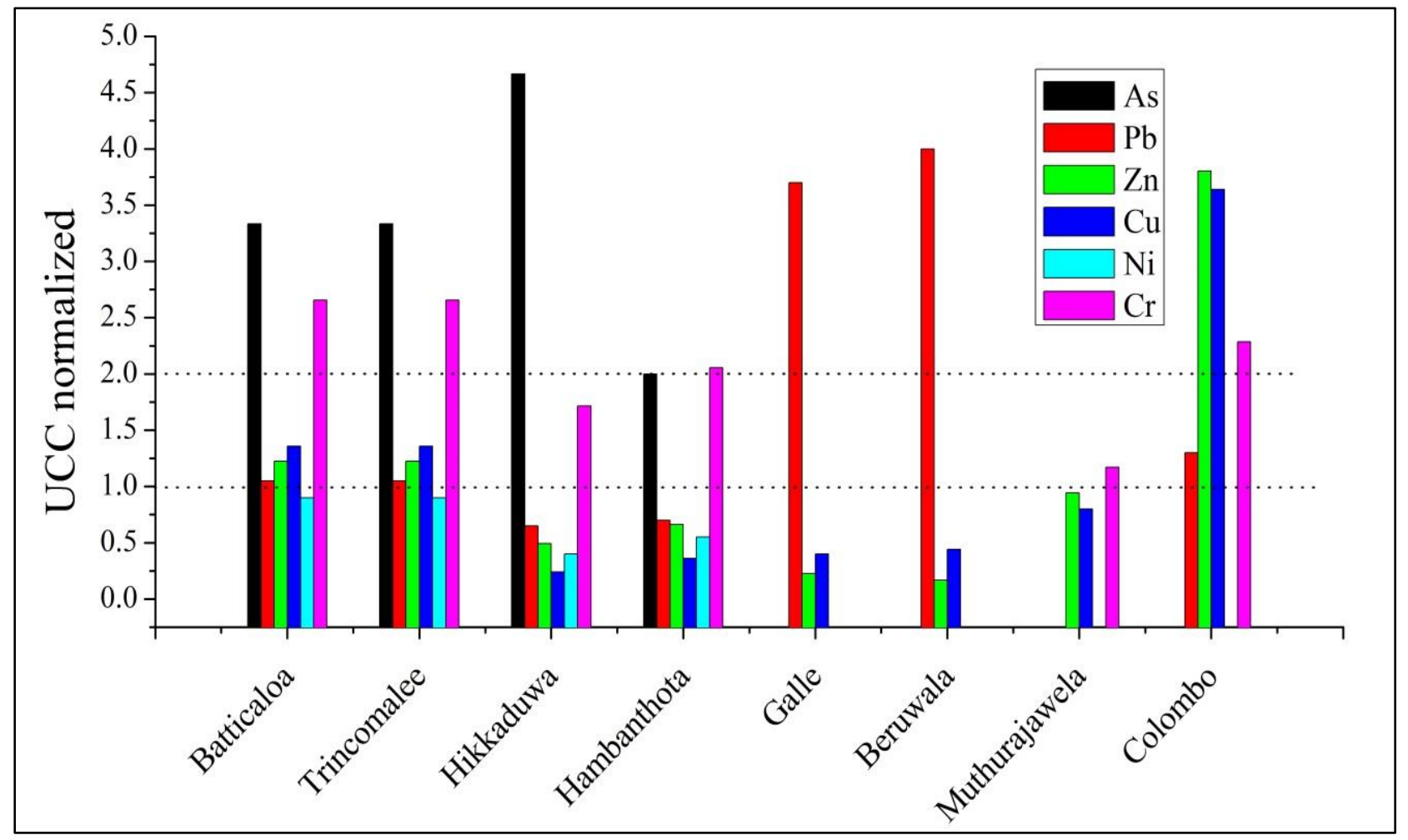

Figure 2: UCC normalized elemental concentrations in coastal sediments of Sri Lanka (After Dissanayake, 1987; Jayawardana et al., 2012; Young et al., 2014; Silva, 2015; Heath et al., 2016; Adikaram et al., 2017).

\section{Environmental and ecological risk assessment of coastal sediments}

Average concentrations of six trace elements of coastal sediments of Sri Lanka are compared with reference values of Threshold Effect Concentration (TEC) and Probable Effect Concentrations (PEC) of consensus-based freshwater ecosystem Sediment Quality Guidelines (Table 1; MacDonald et al., 1996). Values in between TEC and PEC are rarely or occasionally make adverse effects on organisms whereas values above PEC make adverse effects on a wide range of organisms (MacDonald et al., 1996). The average concentrations of As of Sri Lankan coasts are below the threshold values of sediment quality guidelines. In addition, Beruwala and Galle harbors shows above Pbvalues for TEC. The concentrations of $\mathrm{Zn}, \mathrm{Cu}$ and $\mathrm{Cr}$ of Colombo city sediments show higher values for TEC. Except Muthurajawela peaty sediments, all sediment types have exceeded the TEC values for Cr. However, average concentrations of all sediment types of Sri Lankan coasts are below the PEC values suggesting the level of contamination is not much considerable.

Contamination factor $(\mathrm{CF})$ is an elemental ratio of concentration of each metal in the sediment with concentration of those particular metals in the background (Hakanson, 1980). The contamination levels may be classified based on their intensities on a scale ranging from 1 to $6(0=$ none, $1=$ none to medium, 2 
$=$ moderate, $3=$ moderately to strong, $4=$ strongly polluted, $5=$ strong to very strong, $6=$ very strong (Muller, 1969).

$$
C F=\frac{C M_{\text {Sediment }}}{C M_{\text {background }}}
$$

Where:

$C M=$ metal concentration.

The pollution load index (PLI) is calculated using the CF values that provide comparative means to measure the level of pollution in different locations (Tomlinson et al., 1980).

$$
P L I=\sqrt[n]{C F_{1} x C F_{2} x C F_{3} x \ldots x C F_{n}}
$$

Where:

$\mathrm{CF}=$ contamination factor and $\mathrm{n}$ is the number of elements.

If sediments are polluted PLI > 1 and for non-polluted PLI<1 (Tomlinson et al., 1980).

The CF values and PLI values for average concentrations of semi-enclosed coastal bodies of Sri Lanka are given in Table 2. Contamination factor also indicates enrichments of As and $\mathrm{Cr}$ in Sri Lanka coasts. According to the PLI values, Colombo city sediments are significantly polluted. Additionally,Batticaloa lagoon and Trincomalee bay shows slightly polluted sediments whereas other locations are unpolluted with the global references. This is basically due to the high concentrations of $\mathrm{Cr}$ and As which is controlled by the country rocks.

Table 2: Contamination factor, pollution load index and potential ecological risk index of coastal

\begin{tabular}{|c|c|c|c|c|c|c|c|c|}
\hline \multirow[t]{2}{*}{ Location } & \multicolumn{6}{|c|}{ Contamination factor } & \multirow[t]{2}{*}{ PLI } & \multirow[t]{2}{*}{ PERI } \\
\hline & As & $\mathrm{Pb}$ & $\mathrm{Zn}$ & $\mathrm{Cu}$ & $\mathrm{Ni}$ & $\mathrm{Cr}$ & & \\
\hline Batticaloa lagoon & 3.3 & 1.1 & 1.2 & 1.4 & 0.9 & 2.7 & 1.6 & 56 \\
\hline Trincomalee bay & 3.3 & 1.1 & 1.2 & 1.4 & 0.9 & 2.7 & 1.6 & 56 \\
\hline Hikkaduwa lagoon & 4.7 & 0.7 & 0.5 & 0.2 & 0.4 & 1.7 & 0.8 & 57 \\
\hline Hambanthota lagoon & 2.0 & 0.7 & 0.7 & 0.4 & 0.6 & 2.1 & 0.9 & 33 \\
\hline Galle harbour & nd & 3.7 & 0.2 & 0.4 & nd & nd & 0.7 & 21 \\
\hline Beruwalaharbour & nd & 4.0 & 0.2 & 0.4 & nd & nd & 0.7 & 22 \\
\hline Muthurajawela peat & nd & nd & 0.9 & 0.8 & nd & 1.2 & 1.0 & 7 \\
\hline Colombo city & nd & 1.3 & 3.8 & 3.6 & nd & 2.3 & 2.5 & 33 \\
\hline
\end{tabular}
sediments, Sri Lanka.

PLI: pollution load index

PERI: potential ecological risk index 
High metal concentrations in sediments create adverse biological effects which can be measured by several defined approaches. To evaluate the adverse biological effect a simple method introduced by Hakanson (1980) was used. The potential ecological risk index (PERI) is specially proposed to assess the contamination levels of coastal sediments with respect to toxicity of some selected contaminants (Hakanson, 1980).

$$
\begin{aligned}
& \text { PERI }=\sum E_{r} \\
& E_{r}=T_{r} \times C F
\end{aligned}
$$

Where:

$$
\begin{aligned}
& E_{r}=\text { ecological risk factor } \\
& T_{r}=\text { toxic response factor } \\
& C F=\text { contamination factor }
\end{aligned}
$$

The standard values for $\mathrm{T}_{\mathrm{r}}$ are $\mathrm{As}, \mathrm{Pb}, \mathrm{Zn}, \mathrm{Cu}, \mathrm{Ni}$ and $\mathrm{Cr}$ are 10, 5, 1, 5, 5 and 2 respectively. The PERI < 90 is low potential ecological risk; $90<$ PERI < 190 is moderate ecological risk; $190<$ PERI < 380 is considerable ecological risk and PERI > 380 is a very high ecological risk. According to the calculated PERI values with published data, it can be suggested that the Sri Lankan coastal sediments have low potential ecological risk (Table 2).

\section{Summery}

In summary, based on the available data of Sri Lankan coastal sediments, it can be concluded that the sediments are slightly polluted and that level is not adversely affected to the ecological systems. The selection of geochemical background values in contamination status evaluations might be a reason for the pollution status of the present article which is basically depends on the possible source rocks. Regional trace metal concentrations are affected by the rock types, geomorphological conditions and geographical locations which are altered by physical and chemical weathering processes. Therefore, to determine the anthropogenic influences more accurately, a baseline for the sediment trace metal concentrations should be determined regionally. This will help to identify the anthropogenic causes of pollution and take necessary actions to control pollution to prevent the present coastal sediments.

\section{References}

Adikaram, M., Pitawala, A., Ishiga, H., Jayawardana, D., (2017). Spatial distribution, enrichment, and source of environmentally important elements in Batticaloa lagoon, Sri Lanka. Environmental Science and Pollution Research 24(2), 2089-2099.

Chapman, P. M. (2007). Determining when contamination is pollution-weight of evidence determinations for sediments and effluents. Environment International 33(4), 492-501.

Chen, M., Ma, L. Q., (1998). Comparison of four USEPA digestion methods for trace metal analysis using certified and Florida soils. Journal of Environmental Quality 27(6), 1294-1300.

Gao, X., Chen, C. T. A. (2012). Heavy metal pollution status in surface sediments of the coastal Bohai Bay. Water research 46(6), 1901-1911.

Hakanson, L., (1980). An ecological risk index for aquatic pollution control. A sedimentological approach. Water Research 14, 975-1001. 
Hasan, A.B., Kabir, S., Selim Reza, A.H.M., Zaman, M.N., Ahsan, A., Rashid, M., (2013). Enrichment factor and geo-accumulation index of trace metals in sediments of the shipbreaking area of SitakundUpazilla (Bhatiary-Kumira), Chittagong, Bangladesh. Journal of geochemical exploration $125,130-137$.

Herath, D., Pitawala, A., Gunatilake, J. (2016). Heavy metals in road deposited sediments and road dusts of Colombo Capital, Sri Lanka. Journal of the National Science Foundation of Sri Lanka 44(2).

Jayawardana, D.T., Ishiga, H., Pitawala, H.M.T.G.A., (2012). Geochemistry of surface sediments in tsunami-affected Sri Lankan lagoons regarding environmental implications. International journal of environmental science and technology 9, 41-55.

Jonathan, M.P., Ram Mohan, V., (2003). Heavy metals in sediments of the inner shelf off the Gulf of Mannar, Southeast coast of India. Marine pollution bulletin 46, 263-268.

Katupotha, J., (1989). Coastal landforms during the Holocene epoch in Sri Lanka: are they comparable to those in Brazil and Venezuela? International symposium on global changes in South America during the Quaternary, Sao Paulo, Brazil, 188-192.

Katupotha, K.N.J., (2007). (Coastal Landforms) The National Atlas of Sri Lanka, Second Edition, Survey Department of Sri Lanka. 40-42.

MacDonald, D.D., Carr, R.S., Calder, F.D., Long, E.R., Ingersoll, C.G., (1996). Development and evaluation of sediment quality guidelines for Florida coastal waters. Ecotoxicology 5(4), 253-278.

McBride, M. B., (1995). Toxic metal accumulation from agricultural use of sludge: are USEPA regulations protective?. Journal of Environmental Quality 24(1), 5-18.

Muller, G. (1969). Index of Geoaccumulation in Sediments of the Rhine River. GeoJournal 2, 108-118.

Nayanananda, O. K. (2007). The Study of Economic Significance of Coastal Region of Sri Lanka in the Context of Environmental Changes of Pre and Post Tsunami. Coast Conservation Department and The Ministry of Environment and Natural Resources.

Newton, A., Icely, J., Cristina, S., Brito, A., Cardoso, A. C., Colijn, F., Ivanova, K., (2014). An overview of ecological status, vulnerability and future perspectives of European large shallow, semi-enclosed coastal systems, lagoons and transitional waters. Estuarine, Coastal and Shelf Science 140, 95-122.

Ramesh, R., Subramanian, V., (1988). Temporal, spatial and size variation in the sediment transport in the Krishna River basin, India. Journal of hydrology 98, 53-65.

Ranasinghe, P. N., Ortiz, J. D., Moore, A. L., McAdoo, B., Wells, N., Siriwardana, C. H. E. R., Wijesundara, D. T. D. S., 2013. Mid-Late Holocene coastal environmental changes in southeastern Sri Lanka: New evidence for sea level variations in southern Bay of Bengal. Quaternary International298, 20-36.

Sarkar, S.K., Franc`is '̌kovic'-Bilinski, S., Bhattacharya, A., Saha, M., Bilinski, H., (2004). Levels of elements in the surficial estuarine sediments of the Hugli River, northeast India and their environmental implications. Environment international 30, 1089-1098,

Selvaraj, K., Ram Mohan, V., Szefer, P., (2004). Evaluation of metal contamination in coastal sediments of the Bay of Bengal, India: geochemical and statistical approaches. Marine pollution bulletin 49, $174-185$.

Silva, P.N.M.P.D., (2015). Distribution of heavy metals in sediments of Hikkaduwa, Galle, Beruwalafisheriesharbors, Sri Lanka (Unpublished thesis). Post Graduate Institute of Science, University of Peradeniya. 
Solali, A., Ghandi, M.S., Kasilingam, K., Sriraman, E., (2013). Heavy Metal Accumulation in the Surface Sediments off Pondicherry, Bay of Bengal, South East Coast of India. International journal of innovative science, engineering and technology 2(10), 5741-5753.

Subramanian V., Jha, P.K., Jergrieken, R., (1988). Heavy metals in the Ganges estuary. Marine pollution bulletin 19, 290-293.

Taylor, S.R., McLennan, S.M., (1985). The continental crust: its composition and evolution. In: An Examination of the Geochemical Record Preserved in Sedimentary Rocks. Blackwell scientific publications, Oxford, Edinburgh. 1-30.

Tomlinson, D. L., Wilson, J. G., Harris, C. R., Jeffrey, D. W., (1980). Problems in the assessment of heavy-metal levels in estuaries and the formation of a pollution index. HelgoländerMeeresuntersuchungen 33(1), 566.

Tornero, V., d'Alcalà, M. R., (2014). Contamination by hazardous substances in the Gulf of Naples and nearby coastal areas: a review of sources, environmental levels and potential impacts in the MSFD perspective. Science of the total environment 466, 820-840.

Wang, S. L., Xu, X. R., Sun, Y. X., Liu, J. L., Li, H. B., (2013). Heavy metal pollution in coastal areas of South China: a review. Marine pollution bulletin 76(1), 7-15.

Wang, X.L., Sato, T., Xing, B.S., Tao, S., (2005). Health risks of heavy metals to the general public in Tianjin, China via consumption of vegetables and fish. Science of the total environment 350, 28-37.

Young, S. M., Ishiga, H., Roser, B. P., Pitawala, A., (2014). Geochemistry of sediments in three sectors of Trincomalee Bay, Sri Lanka: provenance, modifying factors and present environmental status. Journal of soils and sediments 14(1), 204-217.

Zohra, B. S., Habib, A., (2016). Assessment of heavy metal contamination levels and toxicity in sediments and fishes from the Mediterranean Sea (southern coast of Sfax, Tunisia). Environmental science and pollution research 23(14), 13954-13963. 